\title{
Narrativising a Department of English
}

\author{
Padmakumar $\mathrm{M} \mathrm{M}^{*}$, Gaana $\mathrm{J}^{\dagger}$ and Mohan Kunjukrishna Pillai ${ }^{\ddagger}$
}

\begin{abstract}
The Department of English in a country like India too often witnesses contestations of varied kinds. Debates range from Macaulay's prod to the madness of the method and beyond. Identity crisis - that of the department and that of its members - is one such problematic context. Sidestepping desires to sing notes of self-congratulation, this paper attempts to self-reflexively critique the values, aspirations, practices and its resultant consequences in the Department of English, Christ University, Bangalore. Such a critique will look at specific issues, concerns of, and about English Studies at Christ, based on three experience-enabled narratives. The first narrative aims at exploring 1. complexities of a fresh "pocopomo" (postcolonial-postmodern) English Studies teacher in such a reputed, metropolitan institution, 2. complexities of locating Cultural Studies within an English Studies framework in the institution, and 3. complexities of studentship in such a context.
\end{abstract}

\footnotetext{
* Assistant Professor, Department of Media Studies, Christ University, Bengaluru, India; padmakumar@christuniversity.in

† Assistant Professor, Department of Business Studies and Social Sciences, Christ University, Bengaluru, India; gaana.j@christuniversity.in

‡ Graduate Assistant, McMicken College of Arts and Sciences, University of Cincinnati, University of Hyderabad, Hyderabad, Telangala, India; kunjukmn@mail.uc.edu
} 
The personal is always treated with a sense of suspicion and accompanied by a supposition that it may not be authentic. Humanities - despite the growing disrespect it faces - is one of the last bastions where the personal is not looked downupon. However, when it comes to research, even Humanities expects the shedding of the experiential and the personal, assuming that critical rigour is likely to get compromised. As the authors of this article, it is our firm belief that listening to personal experience will open doors to unexplored critical insights. We are deeply aware of the dangerous terrain we are treading in and hence we have titled it as "narrativising...", signifying the subjective takes involved. Further, the idea of giving multiple accounts coming from different standpoints (that of a new faculty, a moderately experienced faculty and a student) is to highlight the plural nature of experiences and perspectives.

Keywords: English Studies; Higher Education; Cultural Studies; English Departments

\section{Living the "Burden of English": Locating the English Studies Teacher Today}

To be a lecturer in English in India today continues (I consciously use 'continues' here) to be an experience that presents several uncertainties and complexities. While 'the burden of English' might be quite an outdated idea to describe English Studies and its crises (perhaps even hazarding the danger of this burden and crisis being a cliché), for someone who has just begun teaching English Studies, the burden is indeed a new experience. The need to turn to studying and understanding the ramifications of the discipline of English in India was introduced to me during my postgraduate days not very long ago [1]. However, the significance of this selfreflexivity is clarifying itself better only now, as a teacher of English Studies. In this sense, to engage with texts in a "postcolonial, postmodern undergraduate classroom" [2] does indeed throw open several uncertainties and complexities. I have come to realize, however, that these complexities I was introduced to, had thought about and had discussed as a student do not remain the same as I teach now. As a student, the pedagogical implications of a 
discipline were not often ideas that I had consciously engaged with. However, I am being made more conscious of it as I teach English Studies now.

I have been teaching only for a brief period, in a reputed institution in Bengaluru. I have so far taught undergraduate and postgraduate courses. The focus of this paper, would be a self-reflexive understanding of locating the English Studies teacher within issues of pedagogy, curricula, and student attitudes. My attempt here has not been to generalize the Indian classroom (an impossibility, in fact). The purpose of narrativising some of these experiences here is neither in the hope of being able to determine a 'formula' to teach such courses nor to 'redeem' the department at which I teach, but to understand how both teachers, as well as students, respond to specific manners of institutionalized modes of reading the word and the world.

\section{The Institution, Department and its UG programmes}

Christ University was granted autonomy and consequently a deemed-to-be-university status in 2008. The syllabi and curricula, therefore, are designed by the members of the department and are consequently passed in a Board of Studies constituted by the members of the department and externals. The undergraduate courses in this institution move away from the traditional structure of several courses offered as a part of English literature courses. Called 'English Studies' or EST, students are introduced to British and American literatures in the first three semesters and consequently courses like Introduction to Literary Theory, Postcolonial Literatures, Indian Literatures in English, World Literatures are offered alongside optional courses like "Cultural Studies", "English Language Teaching", "Articulating Women" and "Literatures of the Diaspora" in the final semester. These are papers for the regular B.A. courses that have a triple-major system with Psychology and English Studies as two of the three majors. [3] The Honours in English Studies programme has a completely different structure and is not within the focus of this paper primarily because I have not taught the courses 4 [4]. 
Students from different parts of the country and at times, even abroad, are part of these courses. Almost all of them have been educated in English medium schools for most of their education (However, this is not often the case with students enrolling for the B. Com., and B. Sc., courses: many are with a non-English medium of instruction background). This composition dynamic is interesting to my paper primarily because the attitudinal orientation of the students and the newly equipped, "reasonablywell-informed-in-theory" teacher was at huge odds.

\section{Curricula, Pedagogy and Teacher-Student Attitudes}

I shall delineate some of my classroom experiences here to understand the problematics of being an English Studies teacher in a "pocopomo" context. Let me begin with the experience of teaching the paper "Introduction to Literary Criticism and Theory." For someone who had thought about Critical and Cultural Theory as a student, teaching the same to an undergraduate class was indeed a new experience. That literary criticism and theory will enable one to be conscious of the textual nature of nearly everything, and its social and cultural interventions; and the fact that this paper would introduce undergraduate students of English Studies to the various delights of reading cultural texts, become aware of the interdisciplinary nature of their own course combinations was something I looked forward to. However, while I was keen on introducing students to problematising both the discipline and 'texts' within and outside it, I certainly failed in many attempts.

To most students, I discovered, it was least bit problematic that the British literature papers included texts deemed to be "foundational to understanding British literature" (in the words of one of the course instructors) mostly male, canonical writers and few women and marginalized writers. (I am not one of those who belong to the I-hate-great-literature brigade, nor am I against those who are setting out to bring the 'Aesthetic' and 'richness' back). When prodded why they did not deem it necessary to question the idolization of certain writers, they believed that 'Literature' was about richness, aesthetics and values which these writers provide. This was even before they had studied anything about 'New 
Criticism'. (In fact, a colleague even opined that teaching Pope and Dryden was important as they are instrumental in understanding the foundation of British Literature. I wonder what one has to say about the Dorothy Wordsworths and Anna Sewards of the time!) Further discussion and debates and relentless counter-arguments from my side briefly succeeded in making a few people understand the politics of the syllabus and institutionalizing literature[5] that happens in any department of English as a matter of fact.

At this point, to digress a little, I shall share an experience I had at University of Hyderabad, where I pursued my postgraduate studies. It is never difficult to find students from different sections of the society, from various parts of the country studying here. Several of them in the M. A. English course had completed most part of their education in schools with regional languages as their medium of instruction. To them, the daffodils or the Salisbury Plain were indeed alien, things they had never heard of at all. (Of course, being a digital native myself, I had seen images of the daffodils on the internet and other spaces). But to my friends with no access to these sources, the daffodil was just a strange-sounding flower.

This made me realize the denial of an ambivalence that I was experiencing myself. English has been the main language I was brought up in. (The primary school I studied in used to fine any of us who spoke in Kannada!) Although I know other languages, I became conscious of the fact that I did not put my multilingual ability to use; the loss of which is often seen in my classes, too. In fact, several subaltern discourses that I came to familiarize myself with while I was at $\mathrm{UoH}$ made a lot more sense after listening to experiences of several such friends. Manju Dalmia (1993, p.42) has an interesting point to make in the context of a similar feeling of ambivalence in her essay "Derozio: English Teacher": "This ambivalence", she says, "has grown in the process of teaching through the years of trying to bring fundamentally alien texts closer to students who can best understand them as imaginative constructs". In fact, on the contrary, I found that my students were able to relate to non-Indian contexts better than the Indian ones.

Back in this elitist institution, I found that the English classroom was radically different from the ones I had just come out of [6]. English and its "politics of failure" (to borrow S. V. Srinivas' 
terminology) was not a reality in these classrooms. I discovered how students never found it difficult to comprehend the race-classgender discrimination in many of their British and American literature texts owing to their exposure through popular and public culture media, but were very vociferous when it came to understanding the reality behind the discrimination based on caste.

I began to realise that I was living the crisis in English Studies that I had only read and vaguely understood previously. The students were not overtly willing to engage the concerns of the other disciplines that they were studying with those in English Studies. In fact, one of the questions in their End-of-Semester Examination was Freud's formulation of the psychosexual subject to be read alongside ideas of a fragmented / divided 'mind.' Most answers were merely a reproduction of what they had studied in their introductory course in psychology: most essays merely elaborated Freud's psychosexual developmental stages. Perhaps this being their only interdisciplinary approach, even a remote one at that! I then began to wonder if we were merely reiterating Paulo Freire's banking concept of pedagogy.

Yet another space from which, I observed, students often kept away from was the local and national context. They maintained a comfortable distance from significant concerns in these domains. The Literary Theory paper also included a small component of Indian philosophy and aesthetics. I found the placement of this component - at the very end of the syllabus - quite interesting (whether this was a conscious decision or not is indeed a moot point). Since the paper was to be taught in the even-semester (which meant comparatively less number of working days) we not only found that we had run out of time, but also realized that we did not have the expertise to deal with the component and do justice to the area as well as to the students in so little time. The students, however, were extremely grateful for excluding a component from the otherwise formidable "Lit. Theory" paper. The very students who had been able to understand the politics of institutionalizing the discipline were not too keen to engage with the debate as it was a win-win situation for them all, considering the mammoth task of having to prepare for examinations. Students failed to engage with the exclusion at a philosophical, disciplinary 
level of enquiry. No questions were raised about the exclusion of rather local concepts at the cost of ramifications of a cultural and linguistic threat posed by Western epistemology. It was disheartening to see how students were more concerned about what would be tested in the examination rather than anything else[7].

I shall now turn to look at some "success stories" in the classroom. I call them "success stories" because I was able to understand that the classroom discussions did change students' attitudes towards approaching ideas, concepts and domains such as caste. A section on reading and translating caste (with three short stories making up that module) is present in the paper titled "Indian Literatures: Themes and Concerns" for the final year B. A. Regular students who do English Studies. I have enjoyed teaching this paper the most, primarily since it closely engages with concerns of both "Indian" as well as "Literatures." The hazy idea of what constitutes this category has constantly been questioned with the texts in the course to a set of students who were-to quote from Michael Berube's "Cultural Studies and the Cultural Capital" (1998, p.6) "the figure of the graduate student who no longer knows-or, worse, no longer desires to know - what might be 'literary' about literary study". Classroom discussions showed me that some students did manage to understand the problematics of "literary" as well as "India" better on discussing several concerns and possibilities raised in Aijaz Ahmed's seminal essay " 'Indian Literature': Notes Towards the Definition of a Category."

Similarly, most of them had initially viewed Dalit narratives as narratives of exaggeration primarily because they had never seen or read anything like it and hence was difficult to believe what was said. (However, Harry Potter still remains much of the UG class' favourite read). Students were so insensitive to the issue that narratives of manual scavenging were only narratives of the distressed and depressing, most often even gross; most students contributed to discussions on nationalism and Indian modernity in the same course borrowing instances of terrorism and fundamentalism; questions of the Dalit atrocities, for example, were never addressed unless they were asked about it, primarily because 
they had no idea about them despite the heterogeneous constitution of the class.

However, while teaching the module of Caste, I introduced students to Sundar Sarukkai's and Gopal Guru's theorization of the experience of the "Untouchable." They problematize the idea of touch and the body by arguing that the real site of untouchability is indeed in the person who refuses to touch the "untouchable" and the "creation of a supplementary community of untouchables is a necessary consequence of the inability of Brahmins to attain the 'pure' state of untouchable" (197)[8]. The students were finally able to relate to the subaltern concerns with a perspective that was different from what they otherwise identified as "literature of the oppressed" hence, seeking sympathy in their victimhood[9].

Thus, one must begin to relook the approach to English Studies within the concerns and possibilities of the classroom space in a metropolitan institution like the one at which I currently teach. Syllabus and curricula could be evolved by including students if not formally, at least informally, within the process of syllabus formation. Presenting their voices would, indeed, help departments and institutions to consider as well as be conscious of the pedagogical implications in a classroom far more seriously. Teaching the paper "Introduction to Literary Criticism and Theory" has led me to a lot more uncertainties and doubts about the burden of teaching English Studies. The syllabus included introducing significant ideas of philosophers and theorists, their schools. To most of them, much of the poststructuralist feminism made no sense and was an impossibility to achieve; Lacan's theory was difficult to believe: "How could a child look at the mirror and develop a sense of self? What if the child were to live in a household that has no mirror?" they would often ask. It is useful to quote Michael Berube in this context, once again:

I do not lose much sleep worrying about whether my students (graduate or undergraduate) will carry on the work of literary study in the way I like most to see that work done. Nonetheless, it is clear to me that our disciplinary desires and fears are driven as much by our projections of the future as by our assessments of the present (6). 
It is in this spirit that one must understand the position of the English Studies teacher today.

- GaanaJayagopalan Nair

\section{Notes:}

[1] This paper was written at the very beginning of my teaching career at Christ University. While a lot of changes have taken place since then in the English Studies circuit here, those were formative moments of my disciplinary shapings right after having graduated from University of Hyderabad. I must thank Prof. K. Narayana Chandran, Professor, and my Research Supervisor at University of Hyderabad, for introducing several interesting ideas and discussions about the discipline of English during my M.A. and MPhil days, the point of which I see even today in my classroom experiences.

[2] The fact that the undergraduate and the postgraduate English classroom space is characterized by postcolonialities and postmodernities was an assumption, and also at some level, an expectation with which I started off.

[3] The courses are CEP (Communicative English, English Studies and Psychology); JPEng (Journalism, Psychology and English Studies) and PSEng (Psychology, Sociology and English Studies). These are incidentally, the courses that have a higher fee when compared to other traditional B.A. courses, all devoid of psychology and English Studies like HEP (History, Economics and Political Science) and EPS (Economics, Political Science and Sociology).

[4] The Honours programme has a variety of non-traditional papers including Popular Culture Studies, Narratology; Approaches to Reading and Writing; introduction to linguistics among others. Since 2015, a three-year English Honours programme has been introducedat the University's new campus on Bannerghatta Road. A lot of curricular changes were made keeping this new programme 
in mind and were a result of some critical reflections in English Studies curriculum at the Department of English.

[5] Students informed me how that discussion put Terry Eagleton's "The Rise of English" (a part of their syllabus) in perspective for them.

[6] Ironically enough, I had once inhabited the very same classroom during my undergraduate days: I am an alumnus of the institution at which I currently teach.

[7] The Cultural Studies elective paper for the final BA regular students is characterized by a submission of a research paper of about 20-25 pages as a part of their End-Semester Examination. This means that the students do not have to sit through a three-hour long examination at the end of the semester. They have to, instead, work on their research paper through the semester and make the submission on the designated time and date. Several students who opted for the paper came back to me after the initial weeks of the classes and said they had chosen the paper only because it did not include a written examination component.

[8] See Sundar Sarukkai's "Phenomenology of Untouchability" in Sundar Sarukkai and Gopal Guru's Cracked Mirror: An Indian Debate on Experience and Theory (2012).

[9] Some of the students responded that the concept was new, exciting and was an eyeopener, even a visceral experience since it did not seek to equalize the power politics, but reversed it, giving the lower caste a sense of power in their subjugation. I would like to thank Joseph, Mehek, and Sathyavrat for sharing their discussions about caste in the classroom and enhancing my experience of teaching caste in the classroom.

\section{Culture of the Studies in Cultural Studies}

Narratives of Cultural Studies as a domain of knowledge in the Indian academia, have been flexing their muscles within the Humanities and Social Sciences framew ork for a decade and a little more now, with claims of interdisciplinarity, radical potential to awaken/inject political critique and thereby bring about a critical 
sense of 'culture.' Like all narratives, the Indian Cultural Studies narrativestoo operate on a site of contestations, and as in all cases of cultural assertions, here too, a dominant web of positions stake claim for an authentic and long-term hold.

As Imre Szeman points out in his write-up, 'Cultural Studies and the Transnational,' "Even assuming that the narrative of the rise of cultural studies in Birmingham (and for many, its fall in the US) is correct,...the 'transfer' of cultural studies to other intellectual, social, political, national and indeed transnational contexts raises serious and difficult questions about the politics of this intellectual inheritance." Hence, with its affirmative claims of self-reflexivity and rhizomatic sense of origin, the field ought to look at its own constituted-ness, objectives, and destinations with the spirit of critique. Rightfully so, a work like Ratheesh Radhakrishnan's on "Cultural Studies in India: A Preliminary Report on Institutionalisation" (2008) attends to such a demand.

Ratheesh points out that there are a range of origin myths that it relates to and that its practice is as well diverse and at times contradictory. He points out how Tezpur University has a Cultural Studies Programme which operates as though it is Folk Studies and how the Centre for Indian Diaspora and Cultural Studies at Gujarat, addresses the concerns of the affluent Gujarati Diaspora. However, given the broad sweep Ratheesh's article was destined to take - because of its desire to take stock of Cultural Studies in 'India' - there is a failure in attending to particularities.

This paper, with an awareness of being another narrative, attempts to look at a particular set of concerns emerging in a particularised context. It attempts to offer a critique of the Cultural Studies programmesoffered by the Department of English in Christ University, Bangalore. ${ }^{1}$ The project takes a host of concerns that need critical attention, considering the vital role they play in deciding the potency, life and durability of Cultural Studies in spaces like Christ University.

I. Politically Committed Field: Right from its Birmingham birth, the field has been staunchly theorized as a politically committed one. However, a set of problems need closer examination in this paper's context. They are 
- The pro-marginalised, but no-marginalised location

- Institutionalisation and the resultant barriers

- That familiar theory-activism anxiety.

- The pro-marginalised, but no-marginalised location: Stuart Hall, Raymond Williams, and Richard Hoggart had their intentions clear about how the field ought to be a space for enabling newer points of view, favouring the voiceless. No wonder, Stuart Hall, born into a middle-class Jamaican family of African, Indian and British descent, welcomed the contribution of Race Theory and Feminism to add new blood to Cultural Studies. However, in the context of how the field operates in Christ University - as one-paper token acknowledgement in UG English Studies, UG Honours in English Studies and MA in English with Communication Studies - the 'marginalised' concerns starkly stand out. Prior to that, we need to look at the socio-economic givens in the context. The institution, located in a metropolitan city like Bangalore, offers education for the upper middle class and above at an affordable price. While the management is open enough to offer education at a subsidized fee for the economically weak and even offer free education for the academically committed and economically needy, the takers are abysmally low. The reason is predominantly because of the domineering presence of convent-educated students who bring in their on-your-face exhibition of their language skills and competencies. As anybody with a commonsensical understanding of Indian Higher Education would admit, a poor student with government school education will not be able to shore up to the carefully nurtured standards of a convent-educated. And obviously the confidence of such an entrant from a marginalized background gets dented in the very first week and hence there is hardly any scope for continuance. Such being the case, the Cultural Studies paper is accessible only to those who do not fall under the purview of economic or caste-based marginality, which are fundamental in an Indian context. Hence, despite the field enabling promarginalised debates, there is very little scope for the marginalised community to have access.

- Institutional barriers: 
A 'politically committed field' like Cultural Studies needs a university which does not prescribe confinements. It needs a university that practices 'unconditionality' ${ }^{2}$. However, given the academic genuflection ${ }^{3}$ enforced by self-appointed cultural activists and a mute State mechanism, most institutional spaces are likely to bring any knowledge domain under their panopticon study. Hence, the Cultural Studies programmes operate without the teeth they are likely to have when given a free reign. As a result, the Cultural Studies syllabus in Christ Universityis made into an institutionallyacceptable, politically-impotent and status quo-retaining form. A case in point would be the non-accommodation of any LGBT or counter-national or anti-religious text.

\section{- That familiar Theory-Activism anxiety:}

While transcendental figures like Foucault and Derrida could adopt a theory-as-practice and practice-as-theory model, many modest attempts in spaces like Christ University are caught in a fix. On the one hand, there are ideals like Homi Bhabha's "The Commitment to Theory" and on the other, practical difficulties like what the author of The Trouble with Theory, Gavin Kitching (2009) states: “... even the very best students ... fall under postmodernism's sway (that they $)^{4}$ produce radically incoherent ideas about language, meaning, truth and reality. ... Second, since such notions are often used to support politically radical ideas and causes, their basic philosophical weakness in turn weakens those political arguments." This unsure stance on theory has had its plentifulramifications in the classroom like fear and condemnation of theory; theory-enabled escapes and abstractions of socio-political contestations using ideas of relativism, arbitrariness, fluidity, etc.

Further, since most of the students do not have an experiential sense of the marginalised, theory does not enable them to be sensitive in all contexts. For example, two attempts by this teacher to address the knowledge-power nexus reaped different and problematic responses. An Honours in English Studies batch was prompted to think about the ways in which a lot of Indian children's stories exclude the marginalised communities and predominantly work with larger-than-life characters and aristocratic backgrounds. When the alternative possibility of having 
children's stories centering on the Dalits was proposed, many felt upset. A theoretically sound student bluntly stated: "Why would I want my child to learn how the night soiler and his family suffers? Let my child grow up and gradually get to know the harsh realities." Quite like her, many others in the class could not conceptualise that the marginalised have their arts, entertainments, joys, etc. like every other community in the society. For her, the Dalits could only be a sad, depressing adult story that might deserve sympathy. Likewise, when Nero's Guests, a documentary on Farmer Suicides was screened, some students claimed that the narrator P. Sainath was hard-selling and exaggerating the Farmer Suicides. Empowered with the deconstructionist idea of reading as an act of suspicion, they failed to look beyond Sainath's rhetorical flourishes. Leave alone aspirations of Cultural Studies stirring a cultural revolution or produce a Julian Assange or a Zizek, it has problems even in initiating critical human sensitivity.

\section{As an academic Fashion:}

Clare Birchall in the article Cultural Studies and the Secret states, "The suspicion others unleash upon Cultural Studies is that we all just 'sex up' data (recontextualise and reinterpret it, change the wording, order and emphasis) to suit our own purposes, to arrive at a conclusion we've already decided upon in advance. If we check how these are to be made sense of in our context, there are two emerging patterns - one at the level of the department and the other at the level of the student community.

The department, perhaps, out of a desire to stay in the hunt and be academically fashionable, introduced Cultural Studies some eight to ten years ago. However, the Syllabi do not have clarity about their purpose, the receivers and their various subjectivities, and the possible outcomes. For example, the first Cultural Studies syllabus introduced into the mainstream UG English programme had four units - Introduction to Cultural Studies, City, Cinema and the Cyberspace. While the first unit drew a lot from British Cultural Studies lineage, the II, III and IV were heavily influenced by the American Popular Culture as Culture Studies tradition. This choice of texts was not only contradictory, but also unhealthily problematic. 
Likewise, at the students' level in the same context, other set of problems crop up. As part of their minor thesis submission for the end semester, most opt for popular culture areas and do a glorifying job. The faculty, with a strength that is beyond their capacity to guide (usually $50+$ ) and a time (hardly four months to introduce the students to the new field and train them to come up with research work) that is forever closing in, clearly sense their limitations. So students engage with Cultural Studies text, but when it comes to research, predominantly draw material and perspectives from their reservoir of learning from the past. And as Cultural Studies in this BA in English Studies context is an elective, these students get a high of doing something that is 'new' and what many other friends of theirs fail to do.

\section{Uneasy Coexistence}

Cultural Studies has an uneasy co-existence within the English Studies framework. It rubs shoulders with current marketappeasing ELT-Linguistics trends and the traditional languagethrough-literature traditions, provoking a complex mix of responses.

The 'market' forces have prompted a much-theorised corporatisation of education. This has not just lead to the low status of Humanities and Social Sciences, but also to the reformulation of Humanities and Social Sciences. Eg: Applied Economics as opposed to Economics, MA in English with Communication Studies as opposed to the earlier MA English, etc. So, apart from the perennial need for English-speaking employees in many a context, market dynamics in a city like Bangalore demands technical writers, content writers, and linguists for MNCs and the Honours in English Studies and MA in English with Communication Studies courses aid such a project. This is done through a re-envisioning of the English Studies package, leading on to the housing of English Language Teaching, Linguistics, Functional English, etc. In such an atmosphere, a field like Cultural Studies - which Stuart Hall calls to be not submerged within Marxism, but within shouting distance of Marxism - has to wage a losing battle with capitalist forces. 
It is odd, if not amusing to note that a student who has been tutored in Althusser's Ideology and Ideological State Apparatuses, Raymond William's Base and Superstructure in Marxist Cultural Theory and Frederic Jameson's The Cultural Logic of Late Capitalism lands in a plush technical writing job. How reflectively will the person respond to the long, carefully-worded bond of agreement before appointment? How will this person respond to capital? How will this person respond to the absence of labour unions and the (ir)relevance of HR cells? And will the person in any way consider these significant? If these are the trends of employment, how will Cultural Studies assert its relevance in a post-formal education scenario?

While there is the emergence of the market dynamics that needs to be noticed, one cannot ignore the patriarchal liberal humanist figure. Humanism has played and continues its long innings through the benevolence of a faculty who are unwilling to go beyond their comfort zones. In addition, unreflective National Eligibility Tests for lecturers conducted by the government insist on a literature-centered model (certain allowance given to languagecentered approaches). If liberal humanism thrives with ideals of unity in diversity, universality and affirms notions of the author's genius and knowability, Cultural Studies by its very formation and aspirations is against such a project.

With an awareness of such givens, Cultural Studies should rigorously exercise its auto-critique practice and find ways out.

\section{Endnote:}

1. Cultural Studies is offered in three programmes at Christ UG English Studies. Honours in English Studies and MA in English with Communication Studies.

2. Unconditionality is a term that Jacques Derrida uses in his Geneses, Genealogies, Genres, and Genius: The Secrets of the Archive to describe the ways in which a University ought to be first and foremost known for free discussion of any idea.

3. Academic genuflection is a referent to the ways in which educational spaces like Delhi University and the Mumbai 
University were forced to take out texts that were named 'controversial.'

4. The text within brackets in an inclusion on the part of the researcher.

\section{Narrativising a Department of English - a Student's Perspective:}

\section{The subaltern agenda, problems in praxis ${ }^{1}$}

Post the Cultural Studies turn of the 1990s in Indian Higher Education (Dhar, 2011), there has been, what Tejaswini Niranjana calls, "a desire for Cultural Studies" (qtd. in Radhakrishnan, 2008, p.3). Some departments under educational institutions in India have hesitantly made space for critical theory and Cultural Studies within their English Studies courses. Previously the domain of the liberal humanist ${ }^{2}$, now Cultural Studies is engaged in a 'violent' negotiation with the former within English Studies courses. Authors writing in the 1992 anthology edited by Rajeswari Sunder Rajan, The Lie of the Land, ached for, and perhaps in some ways initiated or catalysed, this Cultural Studies turn. More than a decade (an exact time frame is hard to define) into such a turn, and "desire", it is time we took stock of its variedinstitutionalisations, and how its effects are panning out. This paper intends to be one such narrative from a student subject's perspective, having being subjected to experimentations in Cultural Studies (CS) within an undergraduate space (and perpetrator of it, beyond).

The development of CS, and the CS turn, in India is different from its counterparts in Europe and America. Radhakrishnan writes that several developments of the $80 \mathrm{~s}$ and $90 \mathrm{~s}$ have resulted in the opening up of CS in India- one, being the Emergency period of 1975-77, resulting in questions around the concepts of nation and nationhood, and two, being Feminist and Dalit critiques foregrounded by movements during that time (political mobilisation against the Mandal Commission Reports, Babri Masjid demolition and riots that followed etc.). He also surveys an origin story, which roots CS in Subaltern Studies, and another, which defines CS as in the process of "'disciplining' itself" (6). This latter position sees CS as a "domain of knowledge production" - a 
"mode of thinking/research" permeating through and trans disciplines.

CS, at a pedagogical level, works to break down disciplinary boundaries, promoting a "horizontal" integration of human-social sciences and natural sciences (Dhar, 2011, p. 10). It problematises existing disciplines, disciplinary boundaries, and knowledge within the discipline. It examines relations of power, meaning, and spaces of politics "outside of what could be called the 'liberal humanist' or the 'developmentalist' or the 'nation-statist' " (Dhar, 2011 , p. 10). It also, through its examining of the 'low culture' as opposed to 'high culture,' opened space for a "turn to subalternity" (Dhar, 2011, p. 10).

It is such a version of Cultural Studies (both the discipline and the 'approach') that Christ University (formerly Christ College), Bangalore, adopted into its English Studies (department and courses) in the 2000s (it is to be stated here, to be fair, that there are other formulations, aims, and agendas of CS, and that perhaps the one traced above precariously rests on the border of simplification, but this is what best suits, and describes, the Christ University narrative).Centre for Study of Culture and Society (CSCS), an independent centre based in Bangalore, was instrumental in this adoption, and therefore, the ideologies with which that organisation was formed and works operates upon the Culture Studies space at Christ University. The University itself is a private self-financed institution, which caters to mostly a middle, uppermiddle, and upper [financial] class studentship. The courses within the Department of English have a three-pronged approach - liberal humanist; Cultural Studies; and industry-oriented (the third is indicated by English Studies, except for the undergraduate Honours course, being offered only in combination with Psychology or Media/Communication Studies).

Radhakrishnan writes how the relationship between CS and English Studies have been a "tenuous" one (2008, p. 9), and yet the latter is one of the locations where CS was institutionalised in India. Perhaps this is in tune with Jonathan Culler (1972), writing in "Literary Theory in the Graduate Program" , who discusses the English Studies teacher's need to "be able to discuss literature in its relations to more familiar cultural products and in its relations to 
other ways of writing about human experience, such as philosophy, psychology, sociology, anthropology, and history" for literature is only "one aspect of their culture" (qtd. in Kaul, 1992, p. 213). Though, ironically, theory and CS have gone on to criticise precisely the core texts of the humanist tradition that Kaul envisages as to be integrated into English Studies (Kaul, 1992, p. 213-14). Dhar and Radhakrishnan posit the rise of CS in the English Studies space as a result of the disciplinary crises in several disciplines in the 1990s, which led to a rethinking of conceptual and methodological foundations (Dhar, 2011, p. 6; Radhakrishnan, 2008, p. 5). Cultural Studies as a "basket for social sciences and humanities research" (Radhakrishnan 7) gave English Studies the necessary engagement with social sciences during the latter's disciplinary crisis and search for relevance (6).

It is in this space (Christ engaging with CS within English Studies) that $\mathrm{i}^{3}$ wedge my narrative (it needs mention that $\mathrm{i}$ articulate from my subject position as a student of a particular course, and do not claim authoritative knowledge over all variants of CS practised, even within the scope of Christ University; that said, what follows is not uninformed opinion or formulation). What is it for a middleclass student to engage with CS within a middle-class institution (that does not encourage intellectual radicalism)? Posited within the English Studies space, what does the polarities of liberal humanism and CS, both sometimes trying to attack the other, do to the student, as $\mathrm{h}[\mathrm{er} / \mathrm{is}]^{4}$ narrative continues outside the hours in which these are engaged with? How does a middle-class, non-Dalit student make sense of the subaltern agenda? What happens in praxis?

i start with the subaltern agenda and how it engages with the student's background and institutional positions. The subaltern agenda (more in the approach than in the content) is presupposed, taken as a given, almost not open for discussion. The students engaging with the texts and the teacher come from a distinctly nonsubaltern background, often from quite privileged backgrounds. After a year of British Literature, starting with Chaucer and Shakespeare, and ending with Eliot, the student finds h[im/er]self suddenly plunged into theories and essays presupposing the subaltern oppression and the need for empowerment. This results 
in the student's alienation from the text. Examples of this are aplenty in the Christ University narrative, with batches of students having questioned the 'preoccupation with the marginalised' and Dalits. Opportunities for these students to engage with subaltern situations are rare in a city like Bangalore where the polarised class spaces are very much opaque. The very few opportunities that come along are dealt with the middle-class gaze - patronising, sympathetic. This alienation is supported by the construction of the syllabus, which, though attempts to give a introduction to Cultural Studies through essays of Stuart Hall, Raymond Williams, Simon During, and Mrinalini Sebastian, aids not in a historicist understanding of CS, especially in the context of India. And the CS 'approach' to texts is used long before the introduction of CS as a discipline. Within $\mathrm{h}[\mathrm{er} /$ is] academic life, $\mathrm{s} / \mathrm{he}$ is pulled towards subaltern politics on one hand, and liberal humanist tendencies on the other. With essays in CS prescribed along with literary texts, the aim being to adopt a CS reading of the text, and classroom discussions and assignments tending in completely different directions, the CS approach is thwarted. There lies a huge gap between the CS theories, the text at hand, and how the text has been conventionally interpreted. Not to mention the liberal humanist tendencies hard at work. All of these practices adds on the alienation that the student is subjected to.

Engaging with subaltern discourses automatically entails a political and radical aspect. Private educational institutions, especially the ones geared towards the industry, like Christ, are depoliticised campuses. Radical politics is frowned upon, as the "General Regulations" page on the University website explicitly states "students are not expected to indulge in public activities, which are of a political nature" and "Students are forbidden to organize and attend any meeting within the university, or collect money for any purpose or to circulate among the students any notice or petition of any kind...without the written permission of the Vice-Chancellor" (Christ University, 2012). The industry orientation of the institution has no space for what Julian Sefton-Green calls the "system irritant" of Cultural Studies (term borrowed from Dhar, 2011, p. 9) (that said, it is also to be noted that private campuses would find it extremely difficult to keep functioning at an efficient pace if politicised, and could not cater to the industry if it were not for the 
depoliticisation). The student, as a result, faces an obvious contradiction between immediate in and outside class environment. Adding on, the middle-class cosmopolitan student leads, in most cases, a consumerist life in the tending-towardsliberal economy of metropolitan India. This is, again, in sharp contrast with the leftist orientation of $\mathrm{h}[\mathrm{er} / \mathrm{is}]$ academic engagement.

And this brings us to the problems in praxis. The 'demystified' student is plunged into the world which frowns upon nonconformism. As s/he sees hegemony at play in life situations, s/he is left with no option but to look on in pain, for there is no possibility of interfering with the colossal hegemonic patriarchal structures. The student-subject faces this searing pain when s/he encounters the subaltern, or when $\mathrm{s} /$ he, for example, after a month or two of reading feminist discourses, return to h[er/is] own or other patriarchally structured families. When s/he sees advertisements for products like "Fair and Lovely", Edward Said and Asis Nandy whisper in h[er/is] ears. And when s/he sees any advertisement Jameson and Barthes point out the naturalised capital hegemonic power structures at play. When s/he visits certain relatives, or within h[er/is] own family, and members cast a condescending narrative on the lower class and castes, Spivak echoes in $\mathrm{h}$ [is/er] mind. But can s/he intervene positively in any of these situations? The helplessness is hard to negotiate, especially when a majority of the theoreticians and practitioners advocate activism and praxis, right from Plato, or more relevantly, Marx, till Zizek.This is not to deny the subject's capacity to change. Selfdeterminism is possible. Ideological and political stances can inform $\mathrm{h}$ [er/is] own subjectivebehaviour, but even that comes at the cost of social exclusion from many quarters.

$i$ argue that an insufficient imparting of CS, just enough to suit the purposes of English Studies, with little [academic] space within the course to explore more, leaves the student-subject in such a situation, with problems in praxis. From my experience and narratives of co-students, there are four directions of recourse for the student-subject. One is that of being indifferent to the activism/praxis entailment; this would mean a move away from 
CS. The second is that of intentional ignorance or avoidance: treat $\mathrm{h}$ [is/er] life a different entity from the classes $\mathrm{s} / \mathrm{he}$ attend, exercise different subject positions and behaviour for. The third, that of the ivory tower of academics; lead a bourgeoisie life while engaging actively in academics, both in reading and knowledge production, the latter being a move in the direction of positive action, and therefore satisfying the activistic entailment. And finally, fourth, of neurosis; anxiety, helplessness, stuck in a limbo. Possibilities also exist in the negotiation of these directions, especially in different phases of the student-subject's life.

My final argument would be that of the post-course impact. Student life at Christ University is hectic and demanding, enough to keep her/him engaged and not requiring to resort to any of these directions mentioned above but the third (with or without the academic-activist entailment). But once the student-subject leaves the campus, the ivory-tower, the four categories mentioned above begin to play.i would like to close with a personal anecdote. After my undergraduate degree, inspired by the subaltern agenda, i departed on a journey to fight class-caste hegemony, with all the energy my boiling youthful blood could muster. Only to belong, in a couple of months, to the fourth of the categories listed above. To quote from a piece i wrote whilst there,

Who am I/i to be consciously responsible for an O/other's change? Or, who am $\mathrm{I} / \mathrm{i}$ to be responsible for consciously creating/attempting to create an O/other's change? Unless I/I know for myself, and strongly believe. Who am I/i to K/know and believe? What do/can I/i K/know or believe? (Pillai "Objects in the mirror are closer than they appear")

$i$ argue that it is necessary to re-examine, rethink, and restructure exposure to CS in an undergraduate space. What behaviouris seen in graduating students? How can CS be better introduced to a middle-class studentship within an industry-oriented institution with little tolerance for academic activism? Can historicity help? These questions, as a student, $i$ leave for the academia.

[Before i close, it would be harsh if $\mathrm{i}$ were not to recognise and appreciate the space the Department of English at Christ University has opened up for Cultural Studies. It has enabled critical enquiry 
and thought in generations of students, and despite the limitations, have opened up a rare space within a private university. Needless to say, without such a space, i would neither have been exposed to CS, nor would $i$ have been writing this paper. With the spirit of self-reflexivity that CS borrows from the discipline of Philosophy, i humbly dedicate this critique to my teachers, for the betterment of the project they have begun.]

- Mohan K Pillai

\section{Endnotes}

1. While i had not yet come across it when i titled this paper, $\mathrm{i}$ must put on record my borrowing of it from, and gratitude to, the book Theory and Praxis: Curriculum, Culture and English Studies (Prafulla C. Kar, Kailash C. Baral, Sura P. Rath eds. Pencraft International, 2003.)

2. The institutions referred to are middle and upper-middle class institutions, theuniversity in/on which this narrative is based belonging to such a category. For the liberal humanist bias in such institutions, see Gauri Viswanathan ("English In a Literature Society", in The Lie of The Land, Ed. Rajeswari Sunder Rajan, Oxford UP, 1992) and S. V. Srinivas ("The Anatomy of a White Elephant: Notes on the Functioning of English Departments in India", in Subject to Change, Ed. Susie Tharu, Orient Longman, 1997).

3. The uncapitalised " $i$ " is intentionally used. It is a tribute to the move towards subjectivities.

4. Personal pronouns are used gender consciously.

\section{Post Note}

This is a paper presented in the II National Students' Conference on Literary and Cultural Studies at Hyderabad Central University between 25 th -27 th September. While the scenario in the Department of English at Christ University has definitely undergone a series of changes, including the introduction of a three-year Honours in English Studies Programme - the reading of that critical phase is of utmost importance to 
understand the key debates of the moment and how the guiding philosophies and ideologies took charge.

\section{References}

Berube, M. (1998). Employment of English: Theory, Jobs, and the Future of Literary Studies. NY: New York UP.

Bhabha K. H. (2010). The Commitment to Theory. In V. B. Leitch \& W. E. Cain (Eds.), The Norton anthology of theory and criticism. NY: WW Norton \& Company.

Christ University. (2012). General Regulations. Retrieved from http://www.christuniversity.in/general-regulations.

Dalmia, M. (1993). Derozio: English Teacher. In R. S. Rajan (Ed.), The lie of the land: English literary studies in India, Oxford: OUP. Derrida, J. (2006). Geneses, Genealogies, Genres, and Genius: The Secrets of the Archive. (Bie Brahic Beverly Trans.). NY: Columbia University Press.

Dhar, A. "Cultural Studies as Labor of Negotiation in Higher Education".Cultural Studies 25 (1), 71-89.

Guru, G., \& Sarukkai, S. (2012). The Cracked Mirror: An Indian Debate on Experience and Theory. Delhi: Oxford.

Hall, G., \& Birchall, C. (2009). New Cultural Studies: Adventures in Theory. Hyderabad: Orient Blackswan.

Kar, P. C., Kailash, C., \& Rath, S. P. (2003). Theory and praxis: Curriculum, culture and English studies. Delhi: Pencraft International.

Kaul, S. (1992). The Indian Academic and Resistance to Theory. In R. S. Rajan (Ed.), The lie of the land: English literary studies in India, Oxford: OUP.

Kitching, G. (2009). The Trouble with Theory: The Educational Costs of Postmodernism. New South Wales: Allen and Unwin.

Mistral Movies (Producer) \& Bhatia, D (Director). 2009. Nero's Guests: The Age of Inequality. DVD. Print.

Natarajan, S., Joseph, N., \& Srinivas, S. V. (1998). The Anatomy of a White Elephant: Notes of the Functioning of English Departments in India. In S. Tharu (ed.), Subject to Change. Hyderabad: Orient Longman. 
Pillai, M. K. (2012). "Objects in the mirror are closer than they appear".Witness Times. Witness Times, 20 Aug. 2011. Web. 20 Sep. 2012.

Radhakrishnan, R. (2008). Cultural Studies in India: A Preliminary Report on Institutionalisation. Higher Education Cell, CSCS, Bangalore.

Rajan, R. S. (Ed.). (1992). The Lie of the Land: English Literary Studies in India. Delhi: Oxford UP.

Viswanathan, G. (1993). English in a literate society. In R. S. Rajan (Ed.), The lie of the land: English literary studies in India, Oxford: OUP. 